\title{
Sports Diplomacy Research in Poland, Czechia and Slovakia. Emerging Field of Study?
}

\author{
JIŘÍ ZÁKRAVSKÝ, MICHAŁ MARCIN KOBIERECKI \\ AND IVAN ŠTULAJTER
}

\section{sciendo}

Politics in Central Europe (ISSN: 1801-3422)

Vol. 17, No. 3

DOI: 10.2478/pce-2021-0017

\begin{abstract}
Sport is a complex phenomenon that academics across many social sciences are focusing on. The interest in sports has been observable for a long time by historians, anthropologists and sociologists. Scientists in the field of international relations are no exception. A typical way sport is studied in international relations is by paying attention to sports diplomacy. The study of sports diplomacy has become a pretty popular part of the research since the second decade of the $21^{\text {st }}$ century and it is possible to observe the dominance of the authors from the American and British universities in sports diplomacy research. Based on the Web of Science dataset, at first sight, the study of sports diplomacy is not seen as a popular field of research in the Central European countries. On the other hand, this statistical measure does not describe a complex situation of what the sports diplomacy research looks like, how it is formed or how it reflects the thinking of the politicians on national public/sports diplomacy. Thus, the article aims to map sports diplomacy research in the Central European states, specifically in Poland, Czechia and Slovakia.
\end{abstract}

Keywords: sports diplomacy, sport, Poland, Czechia, Slovakia

\section{Introduction}

Sport is one of the most favourite leisure time activities globally; people around the planet decide to spend hours and hours playing sports or watching them. Sport has a huge potential to influence everyday life. Values, such as an emphasis on fair play or friendship, are supported through sport (for instance, 
see Mortimer et al 2021), healthy lifestyle is an integral part of the sporting culture (for instance, see Thorlindsson - Vilhjalmsson - Valgeirsson 1990). Sports stars have become influencers with the ability to acquaint their fans with social and political problems and challenges (for instance, see Schmidt Frederick - Pegoraro - Spencer 2019). Furthermore, sport is often seen as one of the possible components of development strategies (for instance, see Beacom 2007). Sport is, therefore, a complex phenomenon that academics across many social sciences are focusing on. The interest in sports has thus been observable for a long time by historians, anthropologists and sociologists. Scientists in the field of international relations are no exception.

A typical way sport is studied in international relations is focusing on sports diplomacy, which could be described as using '... sports people and sporting events to engage, inform, and create a favourable image amongst foreign publics and organisations to shape their perceptions in a way that is more conducive to achieving a government's foreign policy goals' (Murray 2012: 581). Thus, the main sports diplomacy goal coincides with primary aims of soft power that is, according to Joseph Nye (2005: $\mathrm{x}$ ), 'the ability to get what you want through attraction rather than coercion or payments. It arises from the attractiveness of a country's culture, political ideals, and policies. When our policies are seen as legitimate in the eyes of others, our soft power is enhanced.' A majority of academics interested in sports diplomacy see it as a part of the soft power strategy of the international system actors led by states. For instance, based on the Web of Science database (n. d.), authors of the ten most-cited articles about sports diplomacy published since 2000 reflected sports diplomacy as an element of soft power (for instance, see Grix - Houlihan 2012, Manzenreiter 2010, Merkel 2008) or nation branding (for instance, see L'Etang - Falkheimerb - Lugoa 2007).

However, there is another way to think about sports diplomacy. For instance, it is possible to perceive sports diplomacy as the activities of international sports organisations, without which the organising of international sports events could not take place (Murray - Pigman 2014: 1099). In connection with sports diplomacy, it is now also referred to as 'sports anti-diplomacy' (Murray 2018: 201-247), 'negative sports diplomacy' (Keech 2001: 72) or a 'deviant form of sports diplomacy' (Zákravský 2016: 19). All of these terms describe the use of boycotts of major sporting events as a tool of foreign policy, but also the abuse of sport as a space for visibility for terrorist groups, representatives of undemocratic regimes, etc.

The study of sports diplomacy has become a pretty popular part of the research since the second decade of the $21^{\text {st }}$ century. From 2000 to 2020,165 articles related to sports diplomacy were published in journals indexed in the database Web of Science. Between 2000 and 2010, only eleven articles were published, compared to between 2011 and 2020, in which 154 Web of Science articles on sports diplomacy were published, most of them - 33 - in 2019 (Web of Science 
n.d.). Furthermore, the editors of prestigious academic journals reflected the emerging interest in sports diplomacy study and dedicated their special issue to this topic. For instance, a special issue of The Hague Journal of Diplomacy called Sports Diplomacy was published in 2013 (Murray 2013), Diplomacy \& Statecraft prepared an issue named Diplomacy and Sport three years later (Rofe - Dichter 2016) and, in 2019, Place Branding and Public Diplomacy compiled the Special Issue on Sports Diplomacy (Pamment 2019). These special issues of academic journals are proof of interest in the study of sport in the international context or sports diplomacy research.

The vast majority of the aforementioned sports diplomacy articles - 149 were published in English. Nevertheless, this trend is observed in science in general; English could be described as 'the lingua franca of international publishing' (O'Neil 2018). Furthermore, sports diplomacy research is dominated by the West. A majority of the scientific articles indexed in the Web of Science database were published by academics working at Western universities. According to the Web of Science database, between 2000 and 2020, 36 sports diplomacy articles were published by authors at the universities in the United States of America, 35 by scholars from the British universities and 11 by academics affiliated with the Australian universities. The People's Republic of China is the only non-Western country with more than ten articles, and the local scholars published 11 sports diplomacy articles (Web of Science n.d.). It is possible to observe the dominance of the authors from the American and British universities in sports diplomacy research.

Based on the Web of Science dataset, at first sight, the study of sports diplomacy is not seen as a popular field of research in the Central European countries. If Central Europe is seen only as the Visegrád Group, four articles were published by Hungarian and Polish academics, two by Czech scholars and no article by authors associated with Slovakian universities or research centres. In a more comprehensive view, it is possible to include countries such as Austria, Slovenia and Croatia in Central Europe (for instance, see Hloušek 2007: 34). Nevertheless, the number of articles dealing with sports diplomacy is similar to previous cases, as two have been published at Austrian universities, one in Croatia and none in Slovenia (Web of Science n.d.). Based on this criterion the number of scientific articles included in the Web of Science database - it is evident that sports diplomacy is not such a popular topic of social science research in Central Europe compared to Western countries. On the other hand, this statistical measure does not describe the complex situation of what the sports diplomacy research looks like, how it is formed, what kinds of articles and books focused on sports diplomacy were published or how it reflects the thinking of the politicians on national public/sports diplomacy.

Thus, the article aims to map sports diplomacy research in the Central European states, specifically in Poland, Czechia and Slovakia. Poland is the country in 
which, according to data published by the Web of Science database, the most sports diplomacy articles in the region appear. On the other hand, Slovakia is a country in which, according to the above-mentioned indicator, research on sports diplomacy is underrepresented. Czechia, if it focuses on published articles in the Web of Science database, is the country in which publications on sports diplomacy can be found; however, there are fewer of them than in Poland and Hungary. Thus, the selected countries represent the cases where in the context of the above-mentioned indicator it is possible to talk about a relatively high interest in sports diplomacy (Poland), medium interest (Czechia) and minimal interest (Slovakia).

The article is focused primarily on publishing activities related to sports diplomacy in specific countries, the organisation of conferences and workshops on sports diplomacy, study programmes or the universities where sports diplomacy research takes place. Furthermore, the article deals with the position of the central government and national sports organisations on sports diplomacy and institutional support for studying and practising sports diplomacy. The following part is dedicated to sports diplomacy in Poland. Afterwards, the article deals with the situation in Czechia. The third part focuses on the current position of sports diplomacy in Slovakia.

The authors of the article are academics who focus on sports diplomacy in their research; they are insiders in this field of study. They could be described as promotors of sports diplomacy research at their home universities. The following information in the article is based on the data from the national libraries, research institutions and universities supported by the experience of their own authors, who work as assistants or associate professors at the universities, with sports diplomacy research and practice in their home countries. The article, which is designed as desk research, therefore consists of three specific case studies that map the situation associated with sports diplomacy research in the aforementioned states. It was decided that the cases examined would not be compared; it would be problematic to choose comparative criteria in the context of this topic and their subsequent setting could lead to the oversight of specific aspects that affect the form of sports diplomacy research and study in Poland, Czechia and Slovakia. Thus, the specific case studies are based on three views from three different authors, one each from Poland, Czechia and Slovakia.

\section{Sports Diplomacy Research in Poland}

Sports diplomacy studies, or more generally the interest in sports diplomacy in Poland should be assessed as being in the phase of emergence. In reviewing its development, we should first recall the symposium 'Sport and Diplomacy' dedicated to the interconnection between sports movement and diplomacy, organised by the Polish Olympic Committee in cooperation with the Ministry of Foreign Affairs and the Ministry of Sport and Tourism in Warsaw in October 
2014. The symposium gathered athletes, politicians, sports administrators, civil servants and experts from Poland and several other countries. Among the presentations, particular attention was dedicated to the use of sports events in promoting states internationally. The discussion which proceeded the presentations led to conclusions that the standing of sports diplomacy in Poland should be edhanced (Wilanowicz 2014). This event marked probably the first more formalised approach to deal with the issue of sports diplomacy in Poland, although at this stage it was not directly about scientific research. Rather, the goal of the symposium was to initiate dialogue on the issue and to foster making use of the sports events organised in Poland.

The aforementioned symposium has had several implications. Most directly, it was concluded with formulation of 'Conclusions and Recommendations' appreciating the role of sports diplomacy and recent Polish successes in hosting international sports events and calling for coordination of the diplomacy pursued by the state and by sports organisations, boosting the cooperation with Polish emigrant organisations and engagement in debates concerning the development of world sport (Polski Komitet Olimpijski n.d.). The second direct implication was the publication of the proceedings of the symposium in 2015, a collection of papers presented by respective speakers (Polski Komitet Olimpijski 2015), which appears to be the first Polish monographic publication dedicated entirely to the topic of sports diplomacy.

The year 2014 also marked the increase of recognition of sports diplomacy by the Polish government, which as mentioned contributed to the organisation of the symposium. But the role of sport in improving the reputation of Poland had already been acknowledged earlier. For example, then-Prime Minister Donald Tusk in his expose to the Polish parliament in 2007 spoke about the upcoming UEFA EURO 2012 co-hosted by Poland, describing it as a critical element of the strategy of promoting Poland (Tusk 2007). Still, more formal and direct references to sports diplomacy appeared later. For instance, sports diplomacy has been referred to in two reports issued by the Polish Ministry of Foreign Affairs. In Nowe Wymiary Dyplomacji [New Dimensions of Diplomacy] report for 2013-2014, a separate sub-chapter was dedicated to sports diplomacy within the chapter on the areas of activity of public diplomacy (Ministerstwo Spraw Zagranicznych RP n.d. a). Sports diplomacy, jointly with tourist diplomacy, was also acknowledged by the Ministry of Foreign Affairs in its report on public diplomacy in 2015-2016 (Ministerstwo Spraw Zagranicznych RP n.d. b). Nowadays sport is considered as a regular public diplomacy tool by the Polish government. For example in the open contest 'Public Diplomacy 2021' recently published by the Ministry of Foreign Affairs, sports clubs can apply for funds for the realisation of such public tasks as strengthening the positive Polish image abroad (Ministerstwo Spraw Zagranicznych RP 2021). On the other hand, Poland still lacks a sports diplomacy strategy such as Australia's Sports Diplomacy 2030. 
The research on sports diplomacy in Poland has had a relatively short history and emerged from more established fields of research: politics of sport and public diplomacy. In the first instance, Poland has a relatively long tradition of research concerning the politics of sport, pursued in particular by sports science scholars. In the first place, we should mention Grzegorz Młodzikowski's Polityka $i$ sport [Politics and sport], a monograph published in 1979, which dealt with the interconnections between sport and politics and which strongly referred to international sport. Though already undertaken then, the issue of politics of sport developed more rapidly in Poland in the $21^{\text {st }}$ Century, with many valuable works of research being published, including several monographs such as Sport $w$ Polsce na tle rzeczywistości politycznej lat 1944-1958 [Sport in Poland in the context of political reality between 1944 and 1958] by Piotr Godlewski (2006), Sport wyczynowy w polityce państwa 1944-1989 [Competitive sport in state's policy 1944-1989], Wyścig Pokoju w dokumentach władz partyjnych i państwowych 19481980 [The Peace Race in the documents of party and state authorities 1948-1980] by Artur Pasko (2012; 2009), Sport w cieniu polityki [Sport in the shade of politics] by Dariusz Wojtaszyn (2011) and Polityka sportowa Zwiazku Radzieckiego $i$ Federacji Rosyjskiej [Sports policy of the Soviet Union and Russian Federation] by Artur Podleśny (2019). Many of them had in principle a domestic perspective, but some were more internationally-oriented, for example, Sport w stużbie polityki [Sport in the service of politics] by Jakub Ferenc (2008), Sportowa Wojna Światowa [Sports world war] by Michał Kobierecki (2017) and Bojkot igrzysk olimpijskich jako instrument polityki międzynarodowej w latach 1976-1988 [Boycott of the Olympic Games as an instrument of international politics between 1976 and 1988] by Michał Słoniewski (2016). If sports and international relations is considered, we should also mention the collective work Sport $w$ stosunkach międzynarodowych [Sport in international relations] edited by Andrzej Polus (2009), probably the first Polish scientific publication dedicated entirely to this aspect. These publications, of course, cannot be considered directly as part of the sports diplomacy state of the art in Poland, but many of them did refer to the issues considered in sports diplomacy studies, such as using sport for winning international prestige and to shape interstate relations, or sports boycotts (sometimes considered as negative sports diplomacy or sports anti-diplomacy).

The emergence of sports diplomacy studies in Poland at least to some extent should be associated with a widening of the field of diplomatic studies, particularly in the context of public diplomacy, as sports diplomacy was beginning to be recognised as its useful tool, as in the Ministry of Foreign Affairs reports cited above. Beata Ociepka (2013), one of the most renowned public diplomacy scholars in Poland, stated that sport plays an important role in public diplomacy since it may be used to build an international position of a state. The approach to sports diplomacy from the perspective of public diplomacy has been presented by Michał Kobierecki (2018a), author of Dyplomacja sportowa. Sport w 
działaniach dyplomatycznych państw i aktorów niepaństwowych [Sports diplomacy. Sport in diplomatic activities of states and non-state actors] (Updated book also published in English by Lexington Books/Rowman and Littlefield in 2020). His tripartite theoretical framework to sports diplomacy apart from the use of sport to shape interstate relations and to promote the desired image of a state internationally also included the diplomacy of international sports governing bodies which engage in more traditional forms of diplomacy, but they were in principle considered as external stakeholders of states' public diplomacy.

Apart from Kobierecki's Dyplomacja sportowa, recent books dedicated to sports diplomacy published by Polish authors include MKOl $i$ FIFA jako aktorzy stosunków międzynarodowych [The IOC and FIFA as actors of international relations] by Artur Miazek (2019). The book quite explicitly refers to the concept of sports diplomacy and focuses on the two most important international sports bodies, the IOC and FIFA, as diplomatic actors.

Though not many books dedicated to sports diplomacy have been published by Polish authors so far, the state of the art has been developing rapidly through the publication of articles in scientific journals. The list of authors who have undertaken the issue is long and include Michał Kobierecki (2018b; 2019a; 2019b; 2019c; 2020, etc.), Dariusz Wojtaszyn (2018), Lucyna Słupek (2014), Anna Kobierecka (2018), Marta Studenna-Skrukwa (2018), Grzegorz Skrukwa (2018) and Szymon Pietrzykowski (2017), just to mention a few. Many sports diplomacy papers have been published in a themed issue of Przeglad Zachodni journal dedicated to sport and politics in 2018, revealing that sports diplomacy has been gaining considerable attention among Polish scholars interested in the politics of sport.

In recent years sports diplomacy has also often been undertaken as an area of research in preparation for bachelor's and master's theses at Polish universities. The co-author of this article is also aware of at least one, Ph.D. dissertation under preparation which deals with the issue of sports diplomacy. Sports diplomacy is taught at some Polish universities, although rather in a form of elective courses or within more general courses dedicated to public diplomacy or diplomacy within political science faculties. The perspective for sports diplomacy studies in Poland should therefore be assumed as promising, most importantly because sport has been gaining recognition as a legitimate research subject of political science.

\section{Sports Diplomacy Research in Czechia}

Currently, interest in sports diplomacy by scholars as well as politicians is emerging in Czechia. Nevertheless, research focusing on the relationship between sport and politics in the Czech environment is not an unknown area of interest. Thus, many studies deal with the national gymnastic mass movement 
in the Czech Lands especially with the Sokol movement (for instance, see Krejčí 2002, Libichová 2015, Strachová 2018, Strachová - Vostrý 2018, Uhlír - Waic 2001, Waic 2013 and 2016, Waldauf 2007, 2010a and 2010b), their German rival in the Sudetenland (for instance, see Burian 2012 and 2014, Waic 2014b) and the Czechoslovakian communist Spartakiads (for instance, see Roubal 2003, 2006a, 2006b and 2016). The second widespread topic relates to the Czechoslovakian communist regime and sport that had to coexist with the undemocratic rule (for instance, see Kalous - Kolář 2015, Kolář 2014, Numerato 2010, Waic 2014a). Thus, in Czechia, various historians and sociologists concentrated on study of sport as a political tool.

The research of sports diplomacy in the Czech Republic itself follows up on works that dealt with public diplomacy (for instance, see Peterková 2006, 2008, Tomalová 2008, Novotný 2011, Cabada - Waisová 2012; Waisová - Cabada 2016); after all, in some studies, the use of sport to strengthen the image of the state in the international environment was perceived as part of public diplomacy and did not mention sports diplomacy at all (for instance, see Zákravský 2014). Additionally, the international interest in the way politicians used sport as a part of the foreign policy or soft power strategy influenced Czech academic society as well; international publications reflected that sports diplomacy showed that studying sport could be seen as an important part of international relations research. Furthermore, the attention in studying sports diplomacy was connected with the activity of the Czech government.

In the second decade of the $21^{\text {st }}$ century, Czech politicians definitively realised that sports diplomacy could be a vital part of the Czech self-presentation abroad. A major step that confirmed the Czech government's interest in using the tools of sports diplomacy was the signing of a Memorandum of Mutual Cooperation between the Ministry of Foreign Affairs of the Czech Republic (MFA), represented by the then Minister of Foreign Affairs Lubomír Zaorálek, and the Czech Olympic Committee (COC) in November 2015. The COC was represented by President Jiří Kejval, who spoke about the importance and practicality of this cooperation, because 'sport create[d] 70 per cent of positive outcomes about the Czech Republic abroad' (Ministerstvo zahraničních věcí ČR 2015b). A few months later, in May 2016, similar cooperation was formalised by the signature of a memorandum between the Football Association of the Czech Republic and MFA (Ministerstvo zahraničních věcí ČR 2016). The activities resulting from these memoranda were ideally meant to lead to a positive perception of the Czech Republic in the international environment, which is, after all, the goal for which sport should be used in the context of Czech public diplomacy according to the Czech Republic's Foreign Policy Concept (Ministerstvo zahraničních věcí ČR 2015a: 10). Afterwards, sports diplomacy research became a more important issue for Czech scholars. Proof of this was, for example, the organisation of a conference by the COC and MFA dedicated to sports diplomacy in 2019, 
in which academics from the University of Economics and Business in Prague also participated (Ministerstvo zahraničních věcí ČR 2019), or a series of webinars SPORTDIP in 2021 organised by the Embassy of the Czech Republic in Washington and the $\mathrm{COC}$ in which Czech experts as well as experts from several other countries also participated (Embassy of the Czech Republic in Washington D.C. 2021).

However, the central output of cooperation between academics, sports organisations and the Czech government was creating a one-year study program Sportovni diplomacie [Sports Diplomacy], in 2017. The COC is a key actor supporting the existence of the study program together with the MFA and National Sports Agency. The leading academic partner is a Department of International and Diplomatic Studies, Faculty of International Relations at the University of Economics and Business in Prague (see below); however, foreign universities, such as the Russian International Olympic University or the Matej Bel University in Banská Bystrica, Slovakia, participate as well. The study program Sportovní diplomacie is '... the first comprehensive professional-educational program focused on sports diplomacy in the Czech Republic' (Fakulta mezinárodních vztahů VŠE 2021) and, according to Jana Peterková and Eliška Tomalová (2018: 32), 'this program aims to strengthen the readiness of representatives of Czech sports associations, especially athletes after the end of their active career, to hold positions in international sports institutions. The aim is to strengthen the Czech presence and influence in such institutions, defend Czech interests more effectively, promote Czech sports and thus contribute to the positive perception of the Czech Republic abroad.' Thus, famous Czech athletes were among the first students; for instance, one of the best road and track racing para cyclists in history Jiř́ Ježek, snowboarder and Olympic champion Eva Samková or former basketball player and Czech representative Ilona Burgrová (who is co-author of the article in the special issue Politics in Central Europe; see Kočí - Dubský Burgrová 2021)

In the Czech Republic, it is possible to distinguish two academic institutions where research related to issues of sports diplomacy are part of the systematic research. First, the Department of International and Diplomatic Studies, Faculty of International Relations at the University of Economics and Business in Prague and, second, the Department of Politics and International Relations, Faculty of Arts at the University of West Bohemia in Pilsen.

As mentioned above, the Department of International and Diplomatic Studies at the University of Economics and Business in Prague is the principal academic partner participating in the, MPA (Master of Public Administration) program Sportorní diplomacie. The study program includes, for example, courses focusing on the history of the Olympic movement, sports organisation and finance or sports law, which are taught and guaranteed by the members of the Department of International and Diplomatic Studies such as Štěpánka Zemanová, Radka 
Druláková, Jana Peterková and Zuzana Trávníčková. A coordinator of the study program is Kateřina Kočí, who organised (originally together with her colleague Jana Peterková) the workshop Veřejná prezentace projektů programu Sportovní diplomacie [Public Presentation of Projects at the Sports Diplomacy program] in 2018 and 2019.

Another member of the Department, Zdeněk Dubský (2018), is author of a study called Sportorní diplomacie jako součást zahraniční politiky státu [Sports Diplomacy as the Part of Foreign Policy of State] focusing on theoretical understanding of sports diplomacy. This contribution is probably the most visible scientific article regarding sports diplomacy published by the professors working at the University of Economics and Business in Prague. Furthermore, he and his colleagues participated in the workshops and conferences relating to sports diplomacy and to the role of sport in international relations, organised by the COC or by the Department of Politics and International Relations, the University of West Bohemia.

At the Department of Politics and International Relations, sports diplomacy is seen as a subcategory of public diplomacy as well as soft power strategy. The use of the term 'sports diplomacy' in this context is reflected in the sports diplomacy research and during the teaching process. A prominent figure in this research at the University of West Bohemia is Jiři Zákravský, who is author of probably the first scientific article in the Czech Republic relating to the introduction of how to think/study sports diplomacy called Sport a mezinárodní vztahy. Sportovní diplomacie jako součást zahraniční politiky [Sport and International Relations. Sports Diplomacy as a Part of Foreign Policy] (Zákravský 2016). Furthermore, in his research, he focused on how sport is used as a political tool by the Basque nationalists, emphasising sports diplomacy. The book Baskové $v$ ofsajdu. Sport jako nástroj politiky nestátních národů. Př́padová studie fotbalu $v$ Baskicku [Basques Offside. Sport as a Political Tool of the Stateless Nations. Case Study of football in Basque Country] is one of a few examples, in which he presented sports diplomacy as one of the instruments used by the Basque nationalists to fulfil their political goals (Zákravský 2017). The members of the department published several other articles related to sports diplomacy. Noteworthy examples include an article about Soviet ice-hockey as a foreign policy instrument during the Cold War (Leichtová - Zákravský 2021) published in the prestigious journal Sport in society in 2021 (however, it was accepted for publication and availabe from February 2020), or an article called Sportovmí diplomacie KLDR: Únik $z$ izolace? [Sports Diplomacy of DPRK: Escape from Isolation?] based primarily on Kateřina Vargová's research about the way the political leaders of North Korea thought about sport in the context of their foreign policy (Vargová - Zákravský 2017), which was written for her master's thesis.

The last information in the previous paragraph showed that the students are interested in sports diplomacy and how politicians instrumentalise sport 
as a political instrument. Their interest led the Department of Politics and International Relations to present sports diplomacy in several public events. A few days long summer school Sport a politika $v$ současném světě [Sport and Politics in the Current World] took place in Pilsen in August 2019, where sports diplomacy was discussed with the participants from several universities. The lectures at the summer school were Czech and Slovak experts who focus on sport as a social phenomenon (see Katedra politologie a mezinárodních vztahů FF ZČU 2019). However, in 2020 and 2021, the summer school was cancelled due to the COVID-19 pandemic. On the other hand, in 2020, the online workshop Sport a mezinárodní vztahy [Sport and International Relations] was held, and the experts from the Czech, Slovak and British universities, as well as students who were interested in it, met in the virtual classroom (see Katedra politologie a mezinárodních vztahů FF ZČU 2020).

Both workplaces produce bachelor's and master's theses focusing on sports diplomacy; the interest in this relatively new subject on the part of students of international relations is evident. The topic of sports diplomacy is part of the curriculum at Czech universities; however, these are not primarily separate courses but partial lectures and seminars that deal with the issue. However, people interested in sports diplomacy can participate in the study program Sportovní diplomacie organised by the University of Economics and Business in Prague in cooperation with the COC supported by the MFA and the National Sports Agency. To sum up, even in the Czech Republic, the topic of sports diplomacy is still evolving. It is seen as an integral segment of research in the field of international relations.

\section{Sports Diplomacy Research in Slovakia}

The leading authority in the field of sports diplomacy in Slovakia is the Slovak Olympic and Sports Committee (SOSC). However, the dynamic academic research of sports diplomacy in the first two decades of the $21^{\text {st }}$ century is the result of a creative initiative of associates at the Faculty of Political Sciences and International Relations (FPSIR) at Matej Bel University (MBU) in Banská Bystrica, who identified the prospective direction of pedagogical and scientific research with the aims to develop this field of study, as well as to strengthen the reputation of the university at national and international levels. Both the SOSC and FPSIR have been closely cooperating for over 12 years. Academic activities in sports diplomacy at the Department of International Relations and Diplomacy MBU naturally resulted in signing The Agreement on Cooperation between the SOSC and MBU in the year 2017. This agreement enables MBU students and pedagogical stuff to participate in internships and events organised by SOSC (seminars, sporting events, conferences) and it supports students' research activities in the process of writing their final theses. Reciprocally, SOSC associates 
are invited to participate in various scientific events organised by MBU. Adding to that, new opportunities for cooperation between SOSC and MBU are created in interdisciplinary national and international research projects.

FPSIR at MBU was the first academic workplace in Slovakia that introduced the subject Sportovní diplomacie [Sports Diplomacy] and included it in the master's study program Mezinárodní vztahy [International Relations]. The new subject as well as research activities related to this field of study met with a positive response from both students and cooperating institutions (Ministry of Foreign and European Affairs of the Slovak Republic, Ministry of Education, Science, Research and Sport of the Slovak Republic, The Slovak Olympic and Sports Committee, as well as national sports federations). The research activities and pedagogical process related to teaching the new subject (Sports Diplomacy) was supported by publishing scientific monographs (Terem - Štulajter - Štulajter 2019), university textbooks (Štulajter - Barteková - Štulajter 2013; Štulajter Barteková - Terem 2018), scientific studies and articles (Terem, 2018, Štulajter, 2010, 2011, 2013, 2018). Furthermore, a cooperation with renowned experts from the external environment has been established and research based on interdisciplinary approaches has been gradually developing.

FPSIR at MBU regularly organises a series of conferences entitled Významné športové udalosti z pohladu športovej diplomacie [Significant Sports Events from the Sports Diplomacy Perspective]. Conferences are organised every two years and the first one took place in 2012. The aim of these conferences is to highlight the potential of sport in Slovakia, to develop a professional debate on sports diplomacy, to discuss the issues of soft power of the state in relation to sport and sporting events as well as to explore mutual interconnectedness of sport, diplomacy and politics. Since 2012, in relation to these events, the volumes of scientific papers entitled Významné športové udalosti z pohladu športovej diplomacie [Significant Sports Events from the Sports Diplomacy Perspective] have been published at FPSIR at MBU and focused on the systematisation of the sports diplomacy knowledge base, the analysis and evaluation of specific case studies dealing with initiatives in the field of sports diplomacy, the evaluation of Slovakia's activities in international and European sports federations, raising awareness of the importance of sport in society, its impact on national as well as international politics and the role of sports diplomacy in foreign policy.

Within a scientific project VEGA (1/0949/17) entitled The concept of soft power in the context of the transforming international environment and the potential of its use for national strategies of small states, a university textbook Význam a úlohy športovej diplomacie [The Importance and Tasks of Sports Diplomacy] written by Ivan Štulajter, Danka Barteková and Peter Terem was published in 2018. The textbook is based on both theoretical and empirical bases and points to specific dimensions of the perception of sport as a tool of soft power. The interconnectedness between international sport and diplomacy is well known in the 
theory and practice of diplomacy, but it is relatively underestimated. The above authors provide an inspiring look at the two categories into which international sport and diplomacy converge, as defined by Stuart Murray and Geoffrey Allen Pigman (2014). The first category is international sport, consciously used by governments as a tool of diplomacy. The second category is international sport as diplomacy and concerns diplomatic representation, communication and negotiations between non-state actors, which take place as a result of the ongoing international sporting competition.

Within the framework of the Slovak and Czech cooperation in the sphere of sports diplomacy, a significant example of the international cooperation is the active participation of Ivan Stulajter and Peter Terem from the Department of International Relations and Diplomacy (FPSIR MBU) who taught in the aforementioned study program Sportovni diplomacie in the 2018/19 academic year. For more information about the study programme, see the section Sports Diplomacy Research in Czechia.

As far as current activities of The Slovak Olympic and Sports Committee, SOSC is actively involved as a partner in Erasmus+ projects underway under the leadership of WWTP (Sustainability) and EOC EU Office (Strategic Sports Management). Due to its active approach to events in the international environment and its involvement in international projects, the SOSC is a recognised partner. The development of sports diplomacy in Slovakia is closely related to the growing interest of the SOSC in the participation and membership of its representatives in international sports structures. ${ }^{1}$ Following EU diplomacy (Zints - Parrish, 2019), the Slovak activities in this field strengthen the role of sport and its fundamental values of freedom, democracy, justice, respect for the rule of law and the protection of human rights. It also relates to implementing new approaches to sport as an effective diplomatic tool with huge potential for developing dialogue and building partnerships, with a significant impact on building a cohesive society with benefits in the fields of education, economy, culture and health.

With regard to the fact that Banská Bystrica will be the venue for the organisation of the European Youth Olympic Festival (EYOF 2022), the initiative group of MBU researchers has prepared a project proposal entitled EYOF organization and urban and regional development. The project has an ambition to serve the needs of the organising committee of EYOF, the Municipality of Banská Bystrica and the Banská Bystrica Self-Governing Region. The presented project reflects the need to set up processes and activities so that in the preparation and organisation of an international sporting event there are positive externali-

1 The respected position of the SOSC is indicated by the membership of its representatives in various international Olympic committees and commissions: Jozef Liba - the European Olympic Committee (EOC), Danka Barteková - IOC athletes commission, Jana Daubnerová - EOC athletes commission, Ivana Motolíková - EOC Olympic Education commission, Petra Gantnerová - ENGSO EU Advisory Committee. 
ties and synergies, from which the city and region will benefit not only during the organisation of the sporting event, but also after the event. The aim of the project is therefore to comprehensively analyse and evaluate the impact of the organisation of an international sporting event on the development of the city and region, apply research results in all phases of preparation and implementation of EYOF and include them in strategic plans and documents.

To conclude, sports diplomacy in Slovakia is developing dynamically in the academic as well as external environment. At the Faculty of Political Science and International Relations in Banská Bystrica, sports diplomacy is offered to bachelor's and master's degree students as an optional academic subject for students studying international relations. The majority of these students choose topics from sports diplomacy for their final bachelor's and master's theses. As far as the doctoral study programme is concerned, the Department of International Relations and Diplomacy has had two successful, Ph.D. graduates who focused their dissertation theses on sports diplomacy. In the field of research, sports diplomacy is an integral part of project tasks carried out by the faculty's academic associates who publish their scientific monographs and articles both at home and abroad. Other Slovak universities gradually follow the model provided by MBU in Banská Bystrica and offer sports diplomacy within their study programmes (Comenius University in Bratislava); however, in Slovakia sports diplomacy as an accredited study programme has not yet been introduced.

\section{Conclusion and Discussion}

In Poland, Czechia and Slovakia, increasing interest in sports diplomacy is connected with the enthusiasm of a few researchers who started to think about sport as a foreign policy instrument as well as with recognising the importance of sport by government officials and its use as an appropriate tool that can lead to the creation of a state's reputation in the international system. In this environment, the first scientific articles and books focusing in particular on the general introduction to sports diplomacy were published by Polish, Czech and Slovak scholars. Equally, the initial conferences, workshops and summer schools were organised at Central European universities. Furthermore, an academic sphere started to cooperate with the central governments and national sports organisations headed by the local Olympic Committees that began to focus on a more sophisticated way of using sport for the international presentation of the countries.

The topic of sports diplomacy is also reflected in the study of international relations at Polish, Czech and Slovak universities. Based on the data from the universities, students are interested in the topic of sports diplomacy as well, which can be illustrated by a more significant number of final theses devoted to it. Thus, 
sports diplomacy research in Poland, Czechia and Slovakia could be described as an emerging field of study on the background of international relations.

Another way in which sports diplomacy research can gain further attention in the Central European region is to publish a special issue of a prestigious scientific journal in the field of political science and international relations. The special issue of Politics in Central Europe is the first issue of a scientific journal dedicated to sports diplomacy published in Poland, Czechia or Slovakia. The issue aims to present various studies and aspects connected more or less with sports diplomacy research.

Thus, in the example of the diplomatic relationship between Spain and Kosovo, Fernando Gutiérrez-Chico and Iñigo González-Fuente (2021) showed that sport could be an important tool for defining one actor in the international system vis-à-vis another. Kosovar politicians have used sports diplomacy for the diplomatic recognition of their country, but Spanish officials who do not recognise Kosovo's independence also present their view of Kosovo through sport. Then, Kateřina Kočí, Zbyněk Dubský and Ilona Burgrová (2021) thought about the relationship between equal opportunities, gender and sports diplomacy in the background of Czech basketball. In his study, Danyel Reiche (2021) emphasised the eligibility criteria in rugby, and, in this context, it is possible to talk about 'national representation without citizenship'. At first glance, this may be a topic that is not significantly related to sports diplomacy, but the opposite is true. If the national team is successful, it will ideally lead to the attention of the media and sports fans, and this success can be achieved not a priori by members of the nation but 'only' by members of the national team. Awareness of this state or its prestige is ideally subsequently increased, thanks to success at sporting events. Another study was prepared by Arnošt Svoboda and Simona Šafaříková (2021). They introduced sport as an essential part of development activities and focused on sport for development in general. It is development aid that is perceived as one of the instruments of soft power (Colin 2020), which should ideally, among other things, lead to an improvement in the reputation of the state that provides it.

\section{References}

Alexander, Colin (2020): The Soft Power of Development: Aid and Assistance as Public Diplomacy Activities, in Servaes, Jan ed. Handbook of Communication for Development and Social Change, 407-420, Springer.

Australian Government (2019): Sports Diplomacy 2030, available at: https://www.dfat.gov.au/ sites/default/files/sports-diplomacy-2030.pdf (24 April, 2021). 
Beacom, Aaron (2007): A Question of Motives: Reciprocity, Sport and Development Assistance, European Sport Management Quarterly 7 (1), 81-107.

Burian, Michal (2012): Sudetoněmecké nacionalistické tělovýchovné organizace a československý stát v letech 1918 až 1938, Karolinum.

Burian, Michal (2014): Deutscher Turnverband a československý stát v letech 1918-1933, in Waic, Marek, ed., Češi a Němci ve světě tělovýchovy a sportu, 53-66, Univerzita Karlova v Praze.

Cabada, Ladislav - Waisová, Šárka (2012): Public Diplomacy and Nation Branding as the Instruments of Foreign Policy: Czech Republic in (Central) European Context. Politics in Central Europe 8 (3): 15-44.

Dubský, Zbyněk (2018): Sportovní diplomacie jako součást zahraniční politiky státu, Scientia et Societas 14 (1): 3-21.

Embassy of the Czech Republic in Washington D.C. (2021): SPORTSDIP Series - Discover the World of Sports Diplomacy!, available at: https://www.mzv.cz/washington/en/culture_events/ news/sportsdip_series_discover_the_world_of.html (17 June, 2021).

Fakulta mezinárodních vztahů VŠE (2021):, MPA Sportovní diplomacie, available at: https://fmv. vse.cz/dalsi-moznosti-studia/sportovni-diplomacie (15 June, 2021).

Ferenc, Jakub (2008): Sport w służbie polityki. Wyścig Pokoju 1948-, Wydawnictwo Trio.

Godlewski, Piotr (2006): Sport w Polsce na tle politycznej rzeczywistości lat 1944-1956, Akademia Wychowania Fizycznego im. Eugeniusza Piaseckiego.

Grix, Jonathan - Houlihan, Barrie (2012). Sports Mega-Events as Part of a Nation's Soft Power Strategy: The Cases of Germany (2006) and the UK (2012). British Journal of Politics \& International Relations 16 (4): 572-596.

Gutiérrez-Chico, Fernando - González-Fuente, Iñigo (2021): The Performativity of State Non-Recognition in Sports: The Case of Spain over Kosovo. Politics in Central Europe 17 (3): 421-449.

Hloušek, Vít (2007). Pojem střední Evropy, jeho proměny a milníky politického vývoje, Sborník prací Filozofické fakulty brněnské university: 26-39.

Kalous, Jan - Kolář, František, eds. (2015): Sport v komunistickém Československu 1945-1989, Ústav pro studium totalitních režimů.

Katedra politologie a mezinárodní vztahů FF ZČU (2019): Politika a sport v současném světě, letní škola pro zájemce o sport a politiku 26.-30. srpna 2019, available at: http://kap.zcu.cz/ students/letni-skola-sport.html (15 June, 2021).

Katedra politologie a mezinárodní vztahů FF ZČU (2020): Online workshop „Sport a mezinárodní vztahy", available at: http://kap.zcu.cz/resources/zcu/ad.jsp?did=12422 (15 June, 2021).

Keech, Marc (2001): The Ties that Bind: South Africa and Sports Diplomacy 1958-1963, Sports Historian 21 (1), 71-93.

Kobierecka, Anna (2018): Negatywne konsekwencje dyplomacji sportowej dla wizerunku państwa. Przykład letnich igrzysk olimpijskich w Rio de Janeiro, Przegląd Zachodni 369 (4): 105-116.

Kobierecki, Michał Marcin (2017): "Sportowa wojna światowa”. Implikacje polityczne międzynarodowej rywalizacji sportowej w okresie zimnej wojny, Ibidem. 
Kobierecki, Michał Marcin (2018a): Dyplomacja sportowa: Sport w działaniach dyplomatycznych państw i aktorów niepaństwowych, Wydawnictwo Uniwersytetu Łódzkiego.

Kobierecki, Michat Marcin (2018b): Inter-Korean sports diplomacy as a tool of political rapprochement. Humanities and Social Sciences XXIII (4): 139-153.

Kobierecki, Michał Marcin (2019a): Diplomatic subjectivity of FIFA in the Context of Selecting FIFA World Cup Host. Athenaeum. Polskie Studia Politologiczne 64 (4): 216-231.

Kobierecki, Michat Marcin (2019b): The domestic dimension of sports diplomacy. Przegląd Narodowościowy / Review of Nationalities 9: 17-28.

Kobierecki, Michat Marcin (2020): Recognition of National Football Federations and the Diplomatic Role of FIFA. Polish Political Science Yearbook 49 (2): 158-169.

Kočí, Kateřina - Dubský, Zbyněk - Burgrová, Ilona (2021): Sports diplomacy and gender: equal opportunities for women in Czech basketball. Politics in Central Europe 17 (3): 451-479.

Kolář, František (2014): The Czechoslovak Olympic Movement in 1945-1989, in Waic, Marek et al. In the Shadow of Totalitarianism. Sport and the Olympic Movement in the "Visegrád Countries" 1945-1989, 41-77, Karolinum.

Krejčí, Antonín (2002): Edvard Beneš a Sokol, Společnost Edvarda Beneše.

Libichová, Lenka (2015): Ženský Sokol. Studia Ethnologica Pragensia 2 (2): 102-109.

L'Etang, Jacquie - Falkheimerb, Jesper - Lugoa, Jairo (2007): Public relations and tourism: Critical reflections and a research agenda. Public Relations Review 33 (1): 68-76.

Leichtová, Magda B. - Zákravský, Jiří (2021): Cold War on Ice? Soviet Ice-Hockey Dominance and Foreign Policy, Sport in Society 24 (6): 1033-1054.

Manzenreiter, Wolfram (2010): The Beijing Games in the Western Imagination of China: The Weak Power of Soft Power. Journal of Sport and Social Issues 34 (1): 29-48.

Merkel, Udo (2008): The Politics of Sport Diplomacy and Reunification in Divided Korea: One Nation, Two Countries and Three Flags. International Review for the Sociology of Sport 43 (3): 289-311.

Miazek, Artur (2019): MKOl i FIFA jako aktorzy stosunków międzynarodowych, Scholar.

Ministerstvo zahraničních věcí ČR (2015a): Koncepce zahraniční politiky České republiky, available at: https://www.mzv.cz/file/1565920/Koncepce_zahranicni_politiky_CR.pdf (17 June, 2021).

Ministerstvo zahraničních věcí ČR (2015b): Ministr Zaorálek podepsal Memorandum o vzájemné spolupráci s Českým olympijským výborem, available at: https://www.mzv.cz/jnp/cz/ udalosti_a_media/archiv_zprav/rok_2015/tiskove_zpravy/x2015_11_06_ministr_zaoralek_ podepsal_memorandum.html (17 June, 2021).

Ministerstvo zahraničních věcí ČR (2016): Ministr Zaorálek podepsal Memorandum o spolupráci s Fotbalovou asociací ČR, available at: https://www.mzv.cz/jnp/cz/udalosti_a_media/ archiv_zprav/rok_2016/tiskove_zpravy/ministr_zaoralek_podepsal_memorandum_o.html (17 June, 2021).

Ministerstvo zahraničních věcí ČR (2019): Ministr Petříček zahájil společnou konferenci MZV a ČOV ke sportovní diplomacii, available at: https://www.mzv.cz/jnp/cz/udalosti_a_media/ 
archiv_zprav/rok_2019/tiskove_zpravy/x2019_12_13_konference_mzv_a_cov_ke_sportovni. html (17 June, 2021).

Ministerstwo Spraw Zagranicznych RP (2021): Minister Spraw Zagranicznych ogłasza otwarty konkurs ofert pn. "Dyplomacja publiczna 2021" [Minister of Foreign Affairs announces an open contest of offers titled "Public diplomacy 2021"] (February 2), available at: https:// www.gov.pl/web/dyplomacja/minister-spraw-zagranicznych-oglasza-otwarty-konkurs-ofert-pn-dyplomacja-publiczna-2021.

Ministerstwo Spraw Zagranicznych RP (n.d. a): Nowe Wymiary Dyplomacji. Dyplomacja Publiczna. Raport 2013-2014.

Ministerstwo Spraw Zagranicznych RP (n.d. b): Polska dyplomacja publiczna: 2015-2016.

Mtodzikowski, Grzegorz (1979): Polityka i sport, Wydawnictwo Sport i Turystyka.

Mortimer, Hannah - Whitehead, Jean - Kavussanu, Maria - Gürpınar, Bahri - Ring, Christopher (2021): Values and Clean Sport. Journal of Sports Sciences 39 (5): 533-554.

Murray, Stuart (2012): The Two Halves of Sports Diplomacy. Diplomacy \& Statecraft 23 (3): 576-592.

Murray, Stuart (2013): Sports Diplomacy. The Hague Journal of Diplomacy 8 (3-4): 191-195.

Murray, Stuart (2018): Sports Diplomacy, Origins, Theory and Practice, Routledge.

Murray, Stuart - Pigman, Geoffrey Allen (2014): Mapping the relationship between international. Sport in Society 17 (9): 1098-1118.

Novotný, Lukáš (2011): Trendy vývoje veřejné diplomacie v dnešní zahraniční politice. Politologický časopis 18 (1): 65-79.

Numerato, Dino (2011): Between small everyday practices and glorious symbolic acts: sport-based resistance against the communist regime in Czechoslovakia. Sport in Society 13 (1): 107-120.

Nye, Joseph S. (2005): Soft Power. The Means to Success in World Politics, Public Affairs.

O'Neill, David (2018): English as the Lingua Franca of International Publishing. World Englishes 37 (2): 146-165.

Ociepka, Beata (2013): Miękka siła i dyplomacja publiczna Polski, Scholar.

Pamment, James (2019): Special issue on sports diplomacy. Place Branding and Public Diplomacy 15 (3): 145-146.

Pasko, Artur (2009): Wyścig Pokoju w dokumentach władz partyjnych i państwowych 1948-1980, Avalon.

Pasko, Artur (2012): Sport wyczynowy w polityce państwa 1944-, Avalon.

Peterková, Jana (2006): Veřejná diplomacie - jen módní pojem nebo skutečná změna. Mezinárodní vztahy 41 (3): 83-99.

Peterková, Jana (2008): Veřejná diplomacie, Vydavatelství a nakladatelství Aleš Čeněk.

Peterková, Jana - Tomalová, Eliška (2018): Public Diplomacy, in Kizeková, Alica, ed., Czech Foreign Policy in 2017: Analysis, 324-336, Institute of International Relations.

Pietrzykowski, Szymon (2017): Sport jako alternatywne narzędzie dyplomacji na przykładzie relacji amerykańsko-irańskich po 1979 roku, Dzieje Najnowsze 49 (3): 241-268. 
Podleśny, Artur (2019): Polityka sportowa Związku Radzieckiego i Federacji Rosyjskiej, Scholar.

Polski Komitet Olimpijski (2015): Sport i Dyplomacja [Sport and Diplomacy], Polski Komitet Olimpijski.

Polski Komitet Olimpijski (n.d.): Wnioski i rekomendacje, available at: http://www.olimpijski.pl/ Media/files/WNIOSKI_I_REKOMENDACJE_v2.pdf.

Polus, Andrzej, ed. (2009): Sport w stosunkach międzynarodowych, Wydawnictwo Adam Marszatek.

Reiche, Danyel (2021): National representation without citizenship: the special case of rugby. Politics in Central Europe 17 (3): 501-523.

Rofe, Simon J. - Dichter, Heather L. (2016): Prologue: Diplomacy and Sport. Diplomacy \& Statecraft 27 (2): 207-211.

Roubal, Petr (2003): Politics of Gymnastics. Mass gymnastic displays under communism in Central and Eastern Europe. Body and Society 9 (2): 1-25.

Roubal, Petr (2006a): A didactic project transformed into the celebration of a ritual: Czechoslovak Spartakiads 1955-1990. Journal of Modern European History 4 (1): 90-113.

Roubal, Petr (2006b): „Dnes na Strahově promluví masy“: Proměna symboliky československých spartakiád 1955-1990. Kuděj 8 (2): 79-89.

Roubal, Petr (2016): Československé spartakiády, Academia.

Schmidt, Samuel H. - Frederick, Evan L. - Pegoraro, Ann - Spencer, Tyler C. (2019): An Analysis of Colin Kaepernick, Megan Rapinoe, and the National Anthem Protests. Communication \& Sport 7 (5): 653-677.

Skrukwa, Grzegorz (2018): Megawydarzenia sportowe na obszarze postradzieckim a kreowanie wizerunku państw-gospodarzy, Przegląd Zachodni 369 (4): 117-132.

Słoniewski, Michat (2016): Bojkot igrzysk olimpijskich jako instrument polityki międzynarodowej w latach 1976-1988, Muza.

Słupek, Lucyna (2014): Impreza sportowa jako narzędzie kreacji wizerunku kraju gospodarza, Zeszyty Prasoznawcze 57 (2), 2014: 293-308.

Strachová, Milena (2018): Sokol Brno I - mateřská jednota elitních československých gymnastů. Česká kinantropologie 22 (2): 46-57.

Strachová, Milena - Vostrý, Zdeněk (2018): Brněnské sokolské slety. Brno v minulosti a dnes. Př́spěvky k dějinám a výstavbě Brna 31 (1): 43-63.

Studenna-Skrukwa, Marta (2018): Citius-Altius-Fortius - Igrzyska Olimpijskie w Moskwie w 1980 roku jako strategia promocyjna radzieckiej modernizacji u schyłku epoki Breżniewa, Przegląd Zachodni 369 (4): 89-104.

Svoboda, Arnošt - Šafaříková, Simona (2021): Sport for development in international relations. Politics in Central Europe 17 (3): 481-500.

Štulajter, Ivan (2010): Športová diplomacia a jej význam v medzinárodnom športovom hnutí, in Krnová, Kristína et al. Acta Facultatis Humanisticae Universitatis Matthiae Belii Neosoliensis: vědy o športe, 221-228, Univerzita Mateja Bela. 
Štulajter, Ivan (2011): Nový pohl'ad na súčasnú športovú diplomaciu, in Pajtinka, Erik - Rosputinský, Peter eds. Diplomacia v ére globalizácie: zborník z konferencie k 50. výročiu prijatia Viedenského dohovoru o diplomatických stykoch, 136-142, Univerzita Mateja Bela.

Štulajter, Ivan ed. (2013): Významné športové podujatia v roku 2012 z pohl'adu športovej diplomacie. Zborník vedeckých prác, Belianum.

Štulajter, Ivan - Barteková, Danka - Štulajter, Matúš (2013): Športová diplomacia, Belianum.

Štulajter, Ivan - Barteková, Danka - Terem, Peter (2018): Význam a úlohy športovej diplomacie, Belianum.

Štulajter, Ivan (2018). Globalisation and migration in sports, Forum of foreign languages, Politology and international relations 10 (2): 61-66.

Terem, Peter - Štulajter, Ivan - Štulajter, Matúš (2019): Potenciál športu pre rozvoj mäkkej moci štátu, Naše vojsko.

Terem, Peter (2018): Prínosy športovej diplomacie pre mäkkú moc štátu, in Terem, Peter - Lenč, Marek eds. Mäkká moc a jej význam v medzinárodných vztáahoch v 21. storočí. Teoretické aspekty, regionálne kontexty, 27-41, Belianum.

Thorlindsson, Thorolfur - Vilhjalmsson, Runar - Valgeirsson, Gunnar (1990): Sport Participation and Perceived Health Status: A Study of Adolescents. Soc Sci Med 31(5): 551-556.

Tomalová, Eliška (2008): Kulturní diplomacie. Francouzská zkušenost, Ústav mezinárodních vztahů.

Tusk, Donald (2007): Expose in front of the Parliament of the Republic of Poland, available at: https://tvn24.pl/raporty/expose-donalda-tuska,87 (24 April, 2021).

Uhlî́, Jan Boris - Waic, Marek (2001): Sokol proti totalitě 1938-1952, Karolinum.

Vargová, Kateřina - Zákravský, Jiří (2017): Sportovní diplomacie KLDR: Únik z izolace?, Politické vedy 20 (3): 45-69.

Waic, Marek (2013): Tělovýchova a sport ve službách české národní emancipace, Karolinum.

Waic, Marek (2014a): Sport in Czechoslovakia 1945-1989, in Waic, Marek et al. In the Shadow of Totalitarianism. Sport and the Olympic Movement in the "Visegrád Countries" 1945-1989, 12-39, Karolinum.

Waic, Marek (2014b): Turnerské hnutí a československý stát v letech 1934-1938, in: Waic, Marek ed. Češi a Němci ve světě tělovýchovy a sportu, 247-263, Univezita Karlova v Praze.

Waic, Marek (2016): Tělesná výchova a sport v politickém životě meziválečného Československa, Národohospodářský ústav Josefa Hlávky.

Waisová, Šárka - Cabada, Ladislav (2016): “Branding Tschechien": Public Diplomacy und Nation Branding als Instrumente des Aussenpolitik. Przeglad Europejski 39 (1), 84-106.

Waldauf, Jan (2007): Sokol - malé dějiny velké myšlenky. 1. díl, Atelier IM.

Waldauf, Jan (2010a): Sokol - malé dějiny velké myšlenky. 2. díl: Československé sokolstvo v zahraničí 1952-1975, Atelier IM.

Waldauf, Jan (2010b): Sokol - malé dějiny velké myšlenky. 3. díl: Československé sokolstvo v zahraničí 1976-1995, Atelier IM. 
Web of Science (n.d.): Search: topic: sports diplomacy, available at: https://apps.webofknowledge.com/Search.do?product=WOS \& SID=C4tNktSeXVgwBD2RYJz \& search_ mode=GeneralSearch \& prID=4970dda9-2ecf-4901-bb30-ecf8211d5c62 (28 April, 2021).

Wilanowicz, Mateusz (2014): Sport i dyplomacja, Magazyn Olimpijski. Pismo Polskiego Komitetu Olimpijskiego 109 (4): 16-17.

Wojtaszyn, Dariusz (2011): Sport w cieniu polityki. Instrumentalizacja sportu w NRD, Atut.

Wojtaszyn, Dariusz (2018): Uczeń kontra mistrz. Rywalizacja NRD ze Związkiem Radzieckim i innymi państwami bloku wschodniego, Przegląd Zachodni 369 (4): 73-88.

Zákravský, Jiří (2014). Sport jako nástroj veřejné diplomacie - příklad Kataru, Nový Orient 69 (1): 12-17.

Zákravský, Jiří (2016): Sport a mezinárodní vztahy. Sportovní diplomacie jako součást zahraniční politiky, Central European Journal of Politics 2 (2): 15-36.

Zákravský, Jiří (2017): Baskové v ofsajdu. Sport jako nástroj politiky nestátních národů. Př́padová studie fotbalu v Baskicku, Dokořán.

Zints, Thiery - Parrish, Richard (2019): Promoting a strategic approach to EU sports diplomacy, available at: https://www.edgehill.ac.uk/law/files/2019/05/Sports-Diplomacy-Background-Paper-v2.pdf (28 April, 2021).

Jiř́ Zákravský works as an assistant professor at the Department of Politics and International Relations at the University of West Bohemia in Pilsen, Czech Republic. His central area of research includes sports diplomacy and the use of sport as a political tool in general. E-mail: jirkazak@kap.zcu.cz.

Michal Marcin Kobierecki is an associate professor in the Department of Political Theory and Thought, Faculty of International and Political Studies, University of Lodz. His research interests include sports diplomacy, politics and sport, nation branding and public diplomacy with a specific focus on the use of sport. E-mail: michal.kobierecki@uni.lodz.pl.

Ivan Štulajter is as an assistant professor at the Department of International Relations and Diplomacy, Faculty of Political Science and International Relations, Matej Bel University Banská Bystrica/Slovakia. Since 1998, he focuses his pedagogical and research activities on soft power and sports diplomacy in the context of major sporting national and international events. E-mail: ivan.stulajter@umb.cz. 